\title{
Mutations in B9D1 and MKS1 cause mild Joubert syndrome: expanding the genetic overlap with the lethal ciliopathy Meckel syndrome
}

\author{
Marta Romani ${ }^{1}$, Alessia Micalizzi ${ }^{1,2}$, Ichraf Kraoua ${ }^{3}$, Maria Teresa Dotti ${ }^{4}$, Mara Cavallin ${ }^{5}$, László Sztriha ${ }^{6}$, Rosario Ruta ${ }^{1}$ \\ Francesca Mancini ${ }^{1}$, Tommaso Mazza ${ }^{1}$, Stefano Castellana', Benrhouma Hanene ${ }^{3}$, Maria Alessandra Carluccio ${ }^{4}$, \\ Francesca Darra ${ }^{5}$, Adrienn Máté ${ }^{7}$, Alíz Zimmermann ${ }^{6}$, Neziha Gouider-Khouja ${ }^{3}$ and Enza Maria Valente ${ }^{1,8^{*}}$
}

\begin{abstract}
Joubert syndrome is a clinically and genetically heterogeneous ciliopathy characterized by a typical cerebellar and brainstem malformation (the "molar tooth sign"), and variable multiorgan involvement. To date, 24 genes have been found mutated in Joubert syndrome, of which 13 also cause Meckel syndrome, a lethal ciliopathy with kidney, liver and skeletal involvement. Here we describe four patients with mild Joubert phenotypes who carry pathogenic mutations in either MKS1 or B9D1, two genes previously implicated only in Meckel syndrome.
\end{abstract}

Keywords: Joubert syndrome, Meckel syndrome, Ciliopathies, Primary cilium, MKS1, B9D1, Genotype-phenotype correlates

\section{Findings}

\section{Background}

Joubert syndrome (JS, MIM213300) is a congenital disorder diagnosed by the presence of a peculiar midbrainhindbrain malformation (the "molar tooth sign", MTS), that consists of cerebellar vermian hypodysplasia, thickened mal-oriented superior cerebellar peduncles, and a deepened interpeduncular fossa. The typical neurological features of pure JS include hypotonia, ataxia, psychomotor delay, abnormal ocular movements, intellectual impairment of variable degree, and often breathing abnormalities. This phenotype may be complicated by defects of the kidneys (nephronophthisis), eyes (retinal dystrophy or colobomas), liver (congenital fibrosis), skeleton (mainly polydactyly), and orofacial defects (cleft lip and/or palate, tongue hamartomas), resulting in wide clinical variability $[1]$.

JS is recessively inherited and genetically heterogeneous, with 24 known genes that overall account for about half cases. All genes encode for proteins of the primary cilium,

\footnotetext{
* Correspondence: e.valente@css-mendel.it

${ }^{1}$ IRCCS Casa Sollievo della Sofferenza, Mendel Laboratory, Neurogenetics Unit, San Giovanni Rotondo, Italy

${ }^{8}$ Department of Medicine and Surgery, University of Salerno, Salerno, Italy Full list of author information is available at the end of the article
}

and indeed there is clinical and genetic overlap with other ciliopathies. In particular, JS shares 13 genes with Meckel syndrome (MS, MIM249000), a lethal condition characterized by cystic kidneys, bile duct proliferation of the liver, encephalocele and polydactyly. Other malformations frequently include cleft lip and palate, bowing of long bones and other skeletal defects, and situs inversus [2].

Identification of MKS1 and B9D1 mutations in JS patients As part of a large screening of ciliopathy genes in 260 JS patients, we identified novel pathogenic mutations in two genes not previously implicated in this condition.

Two patients carried mutations in the MKS1 gene [GenBank:NG_013032.1], a 44-year-old man with JS and retinal dystrophy (COR340), and a 2-year-old child with a pure JS phenotype (COR413). Mutations in the B9D1 gene [GenBank:NG_031885.1] were identified in two other patients, a 9-year-old boy (COR363) and a 7-yearold girl (COR346), both presenting with pure JS. All identified mutations were inherited from heterozygous healthy parents, were not reported in public databases, and affected highly conserved residues (Figure 1). Missense mutations were predicted as pathogenic by prediction web tools. Clinical features of the four patients, compared with the phenotypes of the six JS subgroups [1], are summarized 


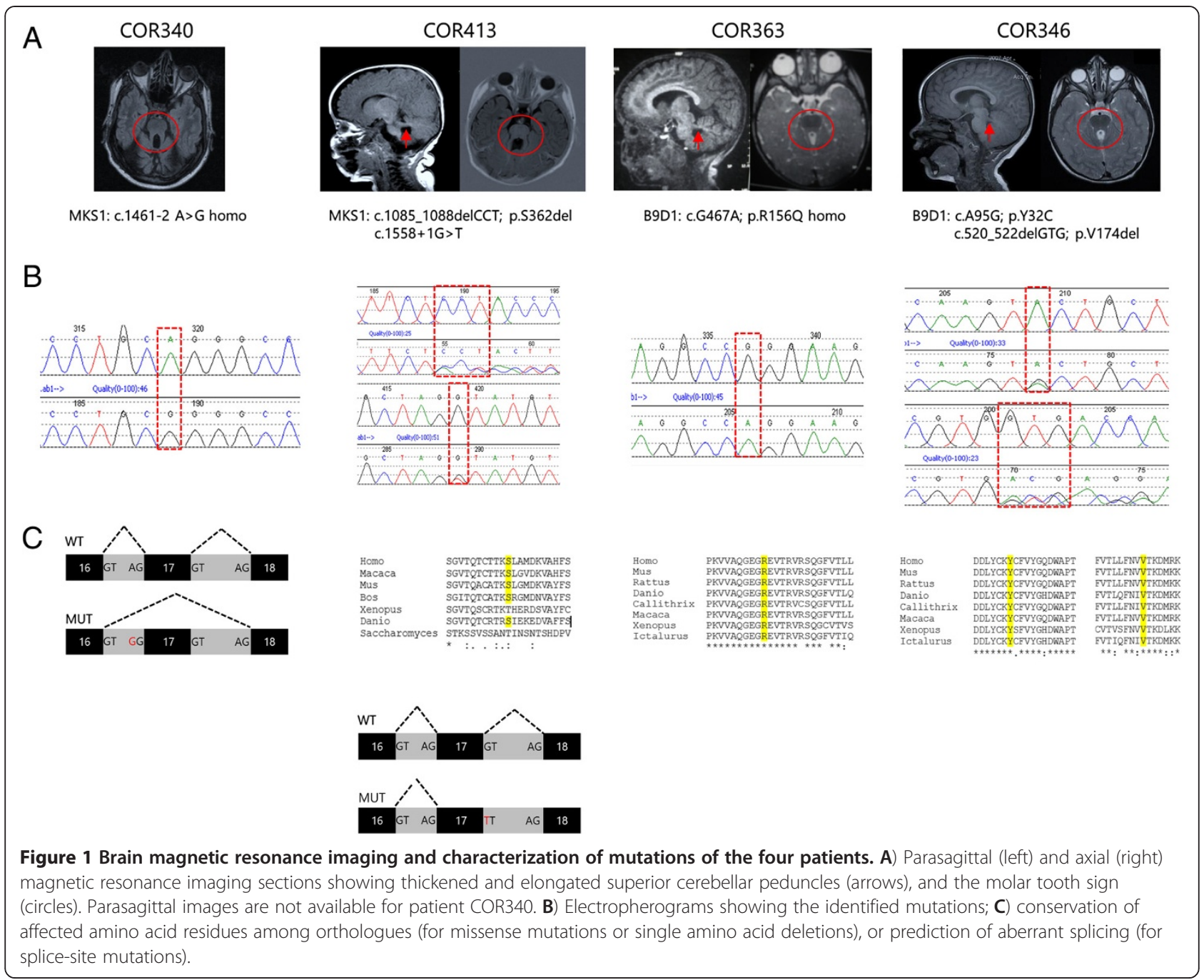

in Table 1. Individual case reports and details on genetic analysis are described in the Additional file 1.

\section{Discussion}

Pathogenic mutations in $M K S 1$ and $B 9 D 1$ have been reported only in MS fetuses. MKS1 is mutated in about $7-14 \%$ of MS patients, with increased frequency in northern European countries due to a founder mutation [3-7]. Several studies have highlighted that mutations in MKS1 are associated with a particularly severe MS phenotype, with high occurrence of polydactyly, bone dysplasia, encephalocele and other central nervous system anomalies [4-6]. To date, B9D1 was found mutated only in one MS fetus with cystic dysplastic kidneys, encephalocele, shortened limbs and ambiguous genitalia [8]. Conversely, the four JS patients described here all had a relatively mild presentation characterized by a pure neurological phenotype, with the exception of retinal dystrophy in patient COR340. The degree of intellectual impairment was variable, and patient COR413 even presented with normal intellectual abilities, a rare occurrence in JS [9]. None of the patients showed involvement of the organs that are typically affected in MS, namely the kidneys, liver and skeleton, although a future renal disease can be safely excluded only in the adult patient (COR340).

This wide phenotypic variability associated with mutations in the same genes remains an intriguing open question. Genotype-phenotype correlates have been proposed for some genes (such as RPGRIP1L, TMEM67, $C C D 2 D 2 A$ and TCTN3), with biallelic null mutations causative of lethal phenotypes, and at least one hypomorphic missense mutation found in JS [10-13]. This could also hold true for $M K S 1$ and $B 9 D 1$. In fact, most MS fetuses are known to carry two null mutations in these genes $[4,8]$; conversely, three of our JS patients have at least one mutation not resulting in protein truncation, and the fourth is homozygous for a splice-site mutation involving the penultimate exon of $M K S 1$, whose 
Table 1 Phenotypic comparison of the four patients presented here with JS clinical subgroups

\begin{tabular}{|c|c|c|c|c|c|c|c|c|c|c|}
\hline & \multicolumn{4}{|c|}{ Present cases } & \multicolumn{6}{|c|}{ JS clinical subgroups (as in ref 1 ) } \\
\hline & $\begin{array}{c}\text { COR340 } \\
\text { (MKS1) }\end{array}$ & $\begin{array}{l}\text { COR413 } \\
\text { (MKS1) }\end{array}$ & $\begin{array}{c}\text { COR363 } \\
\text { (B9D1) }\end{array}$ & $\begin{array}{c}\text { COR346 } \\
\text { (B9D1) }\end{array}$ & Pure & $\begin{array}{l}\text { With } \\
\text { retina }\end{array}$ & $\begin{array}{c}\text { With } \\
\text { kidney }\end{array}$ & $\begin{array}{l}\text { With retina } \\
\text { \& kidney }\end{array}$ & $\begin{array}{l}\text { With } \\
\text { liver }\end{array}$ & OFD-VI \\
\hline \multicolumn{11}{|l|}{ CNS: } \\
\hline - hypotonia/ataxia & + & + & + & + & + & + & + & + & + & + \\
\hline - breathing abn. & - & - & - & - & \pm & \pm & \pm & \pm & \pm & \pm \\
\hline - develop. delay & + & + & + & + & + & + & + & + & + & + \\
\hline$-\mathrm{ID}$ & + & + & + & - & \pm & + & + & + & + & \pm \\
\hline - oculomotor abn.* & + & + & + & + & \pm & \pm & \pm & \pm & \pm & \pm \\
\hline \multicolumn{11}{|l|}{ Ocular: } \\
\hline - retinopathy & + & - & - & - & - & + & - & + & - & - \\
\hline - coloboma & - & - & - & - & \pm & rare & rare & rare & \pm & rare \\
\hline Renal: & - & - & - & - & - & - & + & + & \pm & rare \\
\hline Hepatic: & - & - & - & - & - & - & - & rare & + & - \\
\hline \multicolumn{11}{|l|}{ Other features: } \\
\hline - polydactyly & - & - & - & - & \pm & rare & rare & rare & rare & \pm \\
\hline - orofacial features & - & - & - & - & - & - & - & - & - & \pm \\
\hline - dysmorphisms & + & - & + & + & \pm & \pm & \pm & \pm & \pm & \pm \\
\hline \multicolumn{11}{|l|}{ Neuroimaging: } \\
\hline - MTS & + & + & + & + & + & + & + & + & + & + \\
\hline - other CNS defects** & - & - & - & - & rare & rare & rare & rare & rare & \pm \\
\hline
\end{tabular}

Legend: For the six JS subgroups, the meaning of symbols is as follows: "+": mandatory feature; " \pm ": feature that could be part of the phenotype but is not mandatory; "rare": feature that was only rarely described in the subgroup; "-_: never described to date. *mainly oculomotor apraxia and/or nistagmus; **mostly including corpus callosum hypoplasia, encephalocele, neuronal migration defects (e.g. polymicrogyria), hypothalamic hamartoma (in OFD-VI).

Abbreviations: abn abnormalities, CNS central nervous system, develop developmental, ID intellectual disability of variable severity, MTS molar tooth sign.

pathogenetic impact on the protein remains to be determined (See Additional file 1) (Figure 1). Interestingly, a previous study identified two hypomorphic mutations in the $M K S 1$ gene (a missense change and a single aminoacid deletion) in a 2-year-old Turkish patient with BardetBiedl syndrome, another non-lethal ciliopathy partly overlapping with JS, supporting this hypothesis [14]. Yet, these genotype-phenotype correlates are unlikely to fully explain the extreme phenotypic variability of these allelic ciliopathies, and other mechanisms, such as the presence of modifier variants in other genes, need to be explored.

MKS1, B9D1 and B9D2 proteins are known to interact physically [15], and are main components of the "B9" or "Tectonic" complex residing at the ciliary transition zone, that includes many other proteins mutated in JS and/or MS [16]. In our large JS cohort, $M K S 1$ and $B 9 D 1$ mutations each account for less than $1 \%$ cases. We failed to identify mutations in $B 9 D 2$, but we cannot exclude that this gene may also be rarely mutated in JS.

In conclusion, we expand the genetic basis of JS to include $M K S 1$ and $B 9 D 1$, delineate genotype-phenotype correlates, and further outline JS and MS as the two ends of a common spectrum. These findings have implications for genetic testing and counselling of JS patients and their families.

\section{Additional file}

Additional file 1: Supplementary material. Supplementary Methods.

Prediction of the effect of MKS1 splice-site mutations. Case Reports.

Abbreviations

JS: Joubert syndrome; MS: Meckel syndrome; MTS: Molar tooth sign.

\section{Competing interests}

The authors declare that they have no competing interests.

\section{Authors' contributions}

Patients' recruitment, data collection, analysis of clinical and imaging data: IK MTD, MC, LS, FM, BH, MAC, FD, AM, AZ, NGK, EMV; molecular genetic studies: MR, AM, RR; bioinformatics analysis: TM, SC; study conception and design, manuscript drafting: MR, EMV. All authors revised the manuscript critically and approved the final version.

\section{Acknowledgements}

This work was partly supported by grants from Italian Ministry of Health (Ricerca Corrente 2013, Ricerca Finalizzata Malattie Rare 2008), Telethon Foundation Italy (Grant GGP13145), European Research Council (ERC Starting Grant 260888), National Institute of Health (grant R01NS048453) Tunisian Minister of Health and Tunisian Minister of Scientific Research.

\section{Author details}

${ }^{1}$ IRCCS Casa Sollievo della Sofferenza, Mendel Laboratory, Neurogenetics Unit, San Giovanni Rotondo, Italy. ${ }^{2}$ Department of Medical and Surgical Pediatric Sciences, University of Messina, Messina, Italy. ${ }^{3}$ Research Unit 06/11 and Department of Child and Adolescent Neurology, National Institute Mongi Ben Hmida of Neurology, Tunis, Tunisia. ${ }^{4}$ Department of Medical, 
Surgical and Neurological Sciences, University of Siena, Siena, Italy. ${ }^{5}$ Unit of Child Neuropsychiatry, Policlinico G.B. Rossi, Verona, Italy. ${ }^{6}$ Department of Paediatrics, Faculty of Medicine, University of Szeged, Szeged, Hungary. ${ }^{7}$ Department of Neurosurgery, Faculty of Medicine, University of Szeged, Szeged, Hungary. ${ }^{8}$ Department of Medicine and Surgery, University of Salerno, Salerno, Italy.

Received: 14 January 2014 Accepted: 29 April 2014

Published: 5 May 2014

\section{References}

1. Brancati F, Dallapiccola B, Valente EM: Joubert syndrome and related disorders. Orphanet J Rare Dis 2010, 5:20.

2. Salonen R: The Meckel syndrome: clinicopathological findings in 67 patients. Am J Med Genet 1984, 18:671-689.

3. Kyttala M, Tallila J, Salonen R, Kopra O, Kohlschmidt N, Paavola-Sakki P, Peltonen $\mathrm{L}$, Kestila M: MKS1, encoding a component of the flagellar apparatus basal body proteome, is mutated in Meckel syndrome. Nat Genet 2006, 38:155-157.

4. Khaddour R, Smith U, Baala L, Martinovic J, Clavering D, Shaffiq R, Ozilou C, Cullinane A, Kyttala M, Shalev S, Audollent S, d'Humières C, Kadhom N, Esculpavit C, Viot G, Boone C, Oien C, Encha-Razavi F, Batman PA, Bennett CP, Woods CG, Roume J, Lyonnet S, Génin E, Le Merrer M, Munnich A, Gubler MC, Cox P, Macdonald F, Vekemans M, et al: Spectrum of MKS1 and MKS3 mutations in Meckel syndrome: a genotype-phenotype correlation. Mutation in brief \#960. Online. Hum Mutat 2007, 28:523-524.

5. Auber B, Burfeind P, Herold S, Schoner K, Simson G, Rauskolb R, Rehder H: A disease causing deletion of 29 base pairs in intron 15 in the MKS1 gene is highly associated with the campomelic variant of the Meckel-Gruber syndrome. Clin Genet 2007, 72:454-459.

6. Consugar MB, Kubly VJ, Lager DJ, Hommerding CJ, Wong WC, Bakker E, Gattone VH 2nd, Torres VE, Breuning MH, Harris PC: Molecular diagnostics of Meckel-Gruber syndrome highlights phenotypic differences between MKS1 and MKS3. Hum Genet 2007, 121:591-599.

7. Szymanska K, Berry I, Logan CV, Cousins SR, Lindsay H, Jafri H, Raashid Y, Malik-Sharif S, Castle B, Ahmed M, Bennett C, Carlton R, Johnson CA: Founder mutations and genotype-phenotype correlations in MeckelGruber syndrome and associated ciliopathies. Cilia 2012, 1:18.

8. Hopp K, Heyer CM, Hommerding CJ, Henke SA, Sundsbak JL, Patel S, Patel P, Consugar MB, Czarnecki PG, Gliem TJ, Torres VE, Rossetti S, Harris PC: B9D1 is revealed as a novel Meckel syndrome (MKS) gene by targeted exon-enriched next-generation sequencing and deletion analysis. Hum Mol Genet 2011, 20:2524-2534.

9. Poretti A, Dietrich Alber F, Brancati F, Dallapiccola B, Valente EM, Boltshauser E: Normal cognitive functions in Joubert syndrome. Neuropediatrics 2009, 40:287-290.

10. Iannicelli M, Brancati F, Mougou-Zerelli S, Mazzotta A, Thomas S, Elkhartoufi N, Travaglini L, Gomes C, Ardissino GL, Bertini E, Boltshauser E, Castorina P, D'Arrigo S, Fischetto R, Leroy B, Loget P, Bonnière M, Starck L, Tantau J, Gentilin B, Majore S, Swistun D, Flori E, Lalatta F, Pantaleoni C, Penzien J, Grammatico P, International JSRD Study Group, Dallapiccola B, Gleeson JG, et al: Novel TMEM67 mutations and genotype-phenotype correlates in meckelin-related ciliopathies. Hum Mutat 2010, 31:E1319-E1331.

11. Mougou-Zerelli S, Thomas S, Szenker E, Audollent S, Elkhartoufi N, Babarit C, Romano S, Salomon R, Amiel J, Esculpavit C, Gonzales M, Escudier E, Leheup B, Loget P, Odent S, Roume J, Gérard M, Delezoide AL, Khung S, Patrier S, Cordier MP, Bouvier R, Martinovic J, Gubler MC, Boddaert N, Munnich A, Encha-Razavi F, Valente EM, Saad A, Saunier S, et al: CC2D2A mutations in Meckel and Joubert syndromes indicate a genotype-phenotype correlation. Hum Mutat 2009, 30:1574-1582.

12. Delous M, Baala L, Salomon R, Laclef C, Vierkotten J, Tory K, Golzio C, Lacoste T, Besse L, Ozilou C, Moutkine I, Hellman NE, Anselme I, Silbermann F, Vesque C, Gerhardt C, Rattenberry E, Wolf MT, Gubler MC, Martinovic J, Encha-Razavi F, Boddaert N, Gonzales M, Macher MA, Nivet H, Champion G, Berthélémé JP, Niaudet $P, M c D o n a l d ~ F$, Hildebrandt $F$, et al: The ciliary gene RPGRIP1L is mutated in cerebello-oculo-renal syndrome (Joubert syndrome type B) and Meckel syndrome. Nat Genet 2007, 39:875-881.

13. Thomas S, Legendre M, Saunier S, Bessieres B, Alby C, Bonniere M, Toutain A, Loeuillet L, Szymanska K, Jossic F, Gaillard D, Yacoubi MT, Mougou-Zerelli S, David A, Barthez MA, Ville Y, Bole-Feysot C, Nitschke P, Lyonnet S,
Munnich A, Johnson CA, Encha-Razavi F, Cormier-Daire V, Thauvin-Robinet C, Vekemans M, Attié-Bitach T: TCTN3 mutations cause Mohr-Majewski syndrome. Am J Hum Genet 2012, 91:372-378.

14. Leitch CC, Zaghloul NA, Davis EE, Stoetzel C, Diaz-Font A, Rix S, Alfadhel M, Lewis RA, Eyaid W, Banin E, Dollfus H, Beales PL, Badano JL, Katsanis N: Hypomorphic mutations in syndromic encephalocele genes are associated with Bardet-Biedl syndrome. Nat Genet 2008, 40:443-448.

15. Dowdle WE, Robinson JF, Kneist A, Sirerol-Piquer MS, Frints SG, Corbit KC, Zaghloul NA, van Lijnschoten G, Mulders L, Verver DE, Zerres K, Reed RR, Attié-Bitach T, Johnson CA, García-Verdugo JM, Katsanis N, Bergmann C, Reiter JF: Disruption of a ciliary B9 protein complex causes Meckel syndrome. Am J Hum Genet 2011, 89:94-110.

16. Romani M, Micalizzi A, Valente EM: Joubert syndrome: congenital cerebellar ataxia with the molar tooth. Lancet Neurol 2013, 12:894-905.

doi:10.1186/1750-1172-9-72

Cite this article as: Romani et al:: Mutations in B9D1 and MKS1 cause mild Joubert syndrome: expanding the genetic overlap with the lethal ciliopathy Meckel syndrome. Orphanet Journal of Rare Diseases 2014 9:72.

\section{Submit your next manuscript to BioMed Central and take full advantage of:}

- Convenient online submission

- Thorough peer review

- No space constraints or color figure charges

- Immediate publication on acceptance

- Inclusion in PubMed, CAS, Scopus and Google Scholar

- Research which is freely available for redistribution

Submit your manuscript at www.biomedcentral.com/submit
C Biomed Central 